\title{
FAKTOR YANG MEMPENGARUHI PENDAPATAN PEDAGANG KAKI LIMA (PKL) DI PASAR SUNDAY MORNING (SUNMOR) PURWOKERTO
}

\author{
Muhammad Ammar Allami), Dijan Rahajuni2), Abdul Aziz Ahmad3), Goro Binardjo4) \\ 1),22,3),4) Faculty of Economics and Business, Jenderal Soedirman University \\ Email corresponding author : dijan.rahajuni11@gmail.com
}

\begin{abstract}
Pasar Sunmor adalah pasar yang hanya beraktivitas pada hari Minggu, berlokasi di komplek Gelora Olah Raga (Gor) Satria Purwokerto. Pasar Sunmor muncul karena pada hari minggu di Gor Satria banyak masyarakat yang berdatangan untuk melakukan aktivitas beroleh raga, banyaknya pengunjung dimanfaatkan oleh para pedagang kaki lima untuk menjajakan barang dagangannya. Tujuan penelitian untuk mengetahui faktor-faktor yang mempengaruhi pendapatan pedagang kaki lima di pasar Sunmor Gor Satria Purwokerto. Pengambilan sampel dilakukan secara proportionate stratified random sampling, melalui metode Slovin jumlah sampel terambil sebanyak 90 pedagang. Dalam penelitian ini diduga bahwa yang mempengaruhi pendapatan pedagang kaki lima di pasar Sunmor adalah pendidikan, modal, jam kerja, jumlah tenaga kerja, lokasi berdagang, dan jenis barang dagangan yaitu makanan dan non makanan. Namun berdasarkan hasil analisis melalui alat analisis regresi linear berganda yang mempengaruhi pendapatan pedagang hanya modal, jam kerja dan jenis dagangan. Berdasarkan hal tersebut untuk meningkatkan pendapatan pedagang kaki lima di pasar Sunmor diperlukan : kemudahan dalam akses permodalan melalui kredit perbankan; jam berdagang perlu ditingkatkan melalui pemberian fasilitas tempat berdagang yang memadai dan tidak mengganggu kepentingan pemakai jalan raya, dan perlu adanya peningkatan kualitas pelayanan dalam menjajakan barang dagangannya.
\end{abstract}

Kata kunci : pendidikan, modal, jam kerja, jumlah tenaga kerja, lokasi berdagang, jenis barang dagangan.

\begin{abstract}
Sunmor market is a market that is only active on Sundays, located in the Gelora Olah Raga (GOR) Satria Purwokerto complex. The Sunmor market is there because on Sundays many people come to do sports activities in GOR Satria, it is used by the street vendors to peddle their merchandise. The aim of the study is to determine the factors that influence the income of street vendors at the Sunmor GOR Satria market in Purwokerto. Sampling is done proportionate stratified random sampling, through the Slovin method the number of samples taken is 90 traders. In this study it was assumed that the influencing factors of street venrdors' income in the Sunmor market were education, capital, working hours, number of workers, location of trade, and types of merchandise, i.e food and non-food items. But based on the results of the analysis through multiple linear regression analysis tools, the influencing factors of street vendors' income are capital, working hours, and types of merchandise. Based on this, to increase the street vendors' income on the Sunmor market is needed: ease of access to capital through bank loans; improvement of trading hours through the provision of proper trading facilities that do not interfere with road users' rights, and improvement of service quality in peddling their merchandise.
\end{abstract}

Keywords: education, capital, working hours, number of workers, location of trade, type of merchandise 


\section{PENDAHULUAN}

Pembangunan di wilayah perkotaan dan ketersediaan fasilitas umum yang lebih menarik di wilayah perkotaan, telah menimbulkan arus urbanisasi yang semakin banyak dan menjadi salah satu penyebab permasalahan baru di daerah perkotaan. Urbanisasi yang berlebihan dapat menjadikan kawasan perkotaan menjadi daerah padat penduduk dan menimbulkan permasalahan sosial dan ekonomi (Kuncoro, 2012: 220 - 222), misalnya dalam bidang ketenagaankerjaan. Keterbatasan sektor tenaga kerja formal dalam menampung tenaga kerja menyebabkan para pencari kerja memilih sektor informal sebagai ladang mata pencahariannya. BPS, 2018 menyatakan bahwa mayoritas penduduk Indonesia bekerja disektor informal, yakni sebanyak 56,84 persen dari jumlah penyerapan tenaga kerja. Kondisi yang sama juga terjadi di Provinsi Jawa tengah dan di Kabupaten Banyumas. Di Provinsi Jawa Tengah sektor informal mampu menyerap 60,29 persen dan di Kabupaten Banyumas mampu menyerap 69.19 persen dari jumlah penyerapan tenaga kerja. Lapangan pekerjaan sektor informal yang banyak menyerap tenaga kerja adalah sektor Perdagangan Besar dan Eceran; Reparasi Mobil dan Sepeda Motor/Wholesale and Retail Trade; Repair of Motor Vehicles.

Sektor informal dalam hal ini pedagang kaki lima, yaitu para pedagang yang menjajakan barang dan jasa secara berpindah karena tidak mempunyai tempat yang mapan, sektor informal menjadi pilihan yang menarik bagi sebagian masyarakat yang tidak tertampung di sektor formal. Kelebihan sektor informal diantaranya yaitu mudah untuk dimasuki, karena tidak memerlukan seleksi pendidikan, modal relatif kecil dan tidak terikat pada jam kerja. Namun meskipun demikian untuk dapat menarik pembeli para pedagang juga harus mempunyai ketrampilan dan atau pengetahuan terutama dalam mencari lokasi usaha, memilih jenis barang yang akan diperdagangkan, dan waktu berdagang. Menurut Simanjuntak, 2001, 98 - 100) usaha-usaha yang tergolong sektor informal memiliki ciri-ciri sebagai berikut : 1). Unit usahanya berskala kecil; 2). Dagangannya relatif sederhana; 3). Tidak harus ada ijin usaha; 4). Mudah jika masuk ke pekerjaan informal ; 5). Penghasilan rendah; 6). Terlihat sedikit relasi terhadap bidang lain; 6). Bidang usaha sektor informal sangat beraneka ragam

Kota Purwokerto adalah ibu kota Kabupaten Banyumas yang merupakan pusat pemerintahan, perkantoran, pendidikan, perbankan dan pusat bisnis sehingga memicu masyarakat untuk membuka lapangan pekerjaan sendiri (sektor informal). Gelora olah raga (Gor) Satria yang berada di Jl. Prof. Dr. Suharso No. 99, Purwokerto, adalah merupakan salah satu fasilitas olah raga yang disediakan untuk masyarakat Purwokerto dan sekitarnya. Bahkan pada setiap hari Minggu kawasan Gor Satria dijadikan sebagai kawasan bebas kendaraan (Car Free Day) karena banyak dikunjungi masyarakat untuk melakukan oleh raga, bersamaan dengan itu banyak pedagang yang berdatangan untuk menjajakan barang dagangannya secara 
kaki lima. Banyaknya jumlah pedagang tentu akan mempengaruhi pendapatan mereka, karena persaingan yang semakin ketat, untuk itu maka diperlukan suatu kondisi khusus dari para pedagang untuk dapat mencari peluang dan menarik konsumen agar supaya barang dagangannya laku dan mendapatkan keuntungan yang optimal. Keuntungan dagang bagi pedagang kaki lima adalah merupakan bagian dari pendapatannya.

\section{TINJAUAN PUSTAKA DAN PERUMUSAN HIPOTESIS}

Kajian mengenai persoalan bertambahnya sektor informal tidak lepas dari adanya keterbatasan sektor formal dalam menyerap tenaga kerja dan upaya pelaku ekonomi untuk dapat memenuhi kebutuhan hidupnya. Pedagang kaki lima adalah merupakan salah satu kegiatan yang termasuk dalam sektor informal, dengan cara menjajakan barang dan jasa secara berpindah karena tidak mempunyai tempat usaha yang mapan. Pedagang kakil lima menurut Darman, 2015 : 41-59 adalah sekumpulan orang yang melakukan kegiatan usahanya menggunakan fasilitas umum seperti terotoar, pingir-pingir jalan umum,dan lain sebagainya.

Pendapatan pedaganga kaki lima merupakan penerimaan bersih yang berasal dari pendapatan kotornya dikurangi dengan biaya-biaya (Ardiansyah, 2010 : 242 - 256). Pendapatan bersih ini merupakan laba yaitu selisih antara pendapatan yang diterima dari hasil penjualan barang dan jasa yang dijajakan dikurangi dengan biaya yang dikeluarkan untuk sumber daya yang digunakan untuk membuat barang tersebut (Lipsey, 1990: 176 - 177). Besar kecilnya jumlah pendapatan yang diterima oleh para pedagang kaki lima dipengaruhi oleh banyak variabel, diantaranya pendidikan, modal, jam kerja, jumlah tenaga kerja, lokasi berdagang, dan jenis barang dagangan yaitu makanan, non makanan dan ataupun jasa.

Variabel pendidikan berpengaruh terhadap pendapatan, tingginya tingkat pendidikan memungkinkan meningkatkan pola pikir seseorang dalam pengambilan keputusan bisnis, yang akan berdampak pada peningkatan pendapatan (Hariningsih \& Simatupang , 2008 : 25 - 40), semakin tinggi pendidikan membuat menjadikan semakin terbukanya wawasan seseorang untuk mencari berbagai alternatif solusi yang dihadapinya. Indarti dan Langenberg, 2018 : 114, menyatakan bahwa Pendidikan dan sumber modal terkait secara signifikan dengan kesuksesan bisnis; pendidikan berpengaruh positif dengan hasil usaha (Dickson, Solomon dan Weaver, 2008) dan untuk dapat meningkatkan pendapatan seorang pengusaha Mohammad, Lim, Yusof dan Soon (2015) menyatakan bahwa pendidikan kewirausahaan memberikan pengaruh yang signifikan terhadap menghasilkan wirausaha yang baik sehingga dimungkinkan akan memiliki usaha yang maju dan menghasilkan.

Modal adalah semua bentuk kekayaan yang dapat digunakan secara langsung atau tidak langsung, dalam kaitannya untuk menambah output, lebih khusus dikatakan bahwa modal terdiri dari barang-barang yang dibuat untuk penggunaan produk pada masa yang akan 
datang (Irawan \& Suparmoko, 2008: 125). Secara singkat modal adalah sejumlah uang/ barang yang digunakan untuk kegiatan usaha (Soewartoyo, 2018). Variabel modal ( Fitria, $2014: 1$ 11) berpengaruh terhadap pendapatan pedagang, semakin besar modal yang digunakan maka semakin besar pula pendapatannya, sejalan dengan penelitian tersebut Indarti \& Langenberg, 2008: 1 - 14, membuktikan bahwa modal berpengaruh secara signifikan dengan kesuksesan bisnis. Dengan modal yang cukup seorang pedagang dapat leluasa mengadakan berbagai alternatif barang dagangannya disesuaikan dengan kebutuhan dan selera konsumen.

Jam kerja merupakan durasi waktu yang digunakan untuk menjalankan usaha (Wicaksono, 2011 : 119-124), yang diukur dari lamanya waktu dalam jam yang dilakukan oleh seseorang dalam melakukan pekerjaan setiap harinya. Lamanya jam kerja dalam setiap minggu bagi setiap orang tidak sama, hal ini disebabkan karena beberapa hal diantaranya dikarenakan alasan ekonomi. Semakin banyak jam kerja yang dikorbankan maka produktivitas akan semakin banyak, dan pendapatan yang didapat akan semakin meningkat. Dalam menyediakan waktu untuk bekerja tidak cukup hanya memperhatikan jumlah jam tetapi perlu juga di perhatikan berapa jam kerja setiap orang itu bekerja dalam setiap minggu (Sumarsono, 2009: 30 - 31). Variabel jam kerja menurut Muryati, 2015 : 1 - 8, berpengaruh signifikan terhadap pendapatan pedagang karena dengan jumlah jam kerja yang banyak akan meningkatkan nilai produktifitas pedagang, dengan kata lain akan semakin banyak kesempatan terbuka bagi para pembeli untuk membeli barang dagangannya. Semakin banyak pembeli tentu akan meningkatkan hasil penjualan dan keuntungannya, penelitian Adhikari, 2017 : 1 - 17, pun menyatakan bahwa jam kerja berpengaruh signifikan terhadap pendapatan.

Dalam kaitannya dengan jam kerja, jumlah tenaga kerja yang dipekerjakan untuk melayani pembeli juga perlu diperhitungkan. Tenaga kerja dalam kegiatan usaha termasuk dalam biaya produksi. Banyaknya jumlah tenaga kerja yang dipekerjakan tentu akan menambah beban biaya produksi, dan mengurangi pendapatan.

Lokasi usaha, menurut Tarigan, 2006; 141- 142 terdapat 3 faktor yang mempengaruhi lokasi industri yaitu biaya transportasi yang bertambah secara proposional dengan jarak, upah tenaga kerja serta kekuatan aglomerasi perusahaan. Apabila terdapat produsen dengan barang dagang yang sama dengan lokasi yang berdekatan maka akan terjadi persaingan yang menyebabkan salah satunya gulung tikar atau bahkan hancur semua dan timbul pengusaha baru (Rafiustani, 2016: 1- 15). Memilih lokasi berdagang merupakan keputusan penting untuk bisnis yang harus membujuk pelanggan untuk datang ke tempat bisnis dalam pemenuhan kebutuhannya. Pemilihan lokasi mempunyai fungsi yang strategis karena dapat ikut menentukan tercapainya tujuan badan usaha (Wulan \& Fransisca, 2013 : 109 - 125). Atun, 2016 : 318 - 325, membuktikan bahwa variabel lokasi usaha berpengaruh positif terhadap pendapatan seorang pedagang, pengaruh pemilihan lokasi usaha oleh pedagang kaki lima akan 
mempengaruhi ketertarikan dan kenyamanan konsumen untuk singgah dan membeli barang dagangannya. Banyaknya konsumen yang membeli barang dagangannya sudah barang tentu akan meningkatkan pendapatan dan keuntungan pedagang. Dalam pemilihan lokasi perlu diperhatikan (Tjiptono, 2008: 198) keterjangkauan lokasi, kelancaran akses menuju lokasi dan kedekatan lokasi

Penelitian Atun, 2016 : 318 - 325, menyatakan bahwa jenis barang dagangan memiliki pengaruh terhadap variabel pendapatan. Oleh karena itu seorang pedagang harus mengetahui kebutuhan dan selera konsumen. Melalui analisa pasar dan segmentasi pasar seorang pedagang akan dapat melihat peluang barang apa yang dibutuhkan konsumen pada saat itu. Kemampuan pedagang untuk dapat menganalisa kondisi pasar dapat dilakukan melalui pengamatan dan atau survai pasar.

Penyusunan hipotesis penelitian ini disadarkan bahwa tingkat pendidikan, modal, jam kerja, jumlah tenaga kerja, lokasi usaha dan jenis dagangan berpengaruh terhadap pendapatan pedagang kaki lima di pasar Sunmor Gor Satria Purwokerto.

\section{METODE PENELITIAN}

Penelitian ini merupakan survey yang dilakukan pada pedagang di Pasar Sunmor Gor Satria Purwokerto. Tehnik pengumpulan data dilakukan melalui wawancara, kuesioner, dan observasi (Arintuko,2010 : 270 -272). Pengambilan sampel dalam penelitian ini dilakukan dengan metode proportionate stratified random sampling, yaitu cara pengambilan sampel dengan memperhatikan strata (tingkatan) di dalam populasi (Sugiyono, 2017: 64). Penentuan jumlah sampel dilakukan dengan cara mencari populasi yang diketahui, kemudian tentukan tingkat presisi yang ditetapkan (Riduwan \& Engkos, 2012: 44), dengan menggunakan rumus slovin sebagai berikut:

$$
n=\frac{N}{N\left(d^{2}\right)+1}
$$

Keterangan :

$$
\begin{aligned}
& \text { N : Besarnya Polulasi } \quad \text { d } \quad \text { : Tingkat presisi/ siginikan (10\%) } \\
& \text { n : Besarnya sampel }
\end{aligned}
$$

dengan jumlah populasi sebanyak 759 pedagang, yang terdiri dari 233 kelompok pedagang makanan dan 526 kelompok pedagang non makanan, maka sampel yang terambil sebanyak 90 pedagang, sampel pedagang makanan sebanyak 28 pedagang dan sampel pedangan non makanan sebanyak 62 pedagang.

Untuk membuktikan dihopotesis dianalisis melalui regresi berganda sebagai berikut (Ghozali, 2011: 94).

$$
\operatorname{Ln} Y=\beta_{0}+\beta_{1} X_{1}+\beta_{2} X_{2}+\beta_{3} X_{3}+\beta_{4} X_{4}+\beta_{5} X_{5}+\beta_{6} D_{1}+e
$$




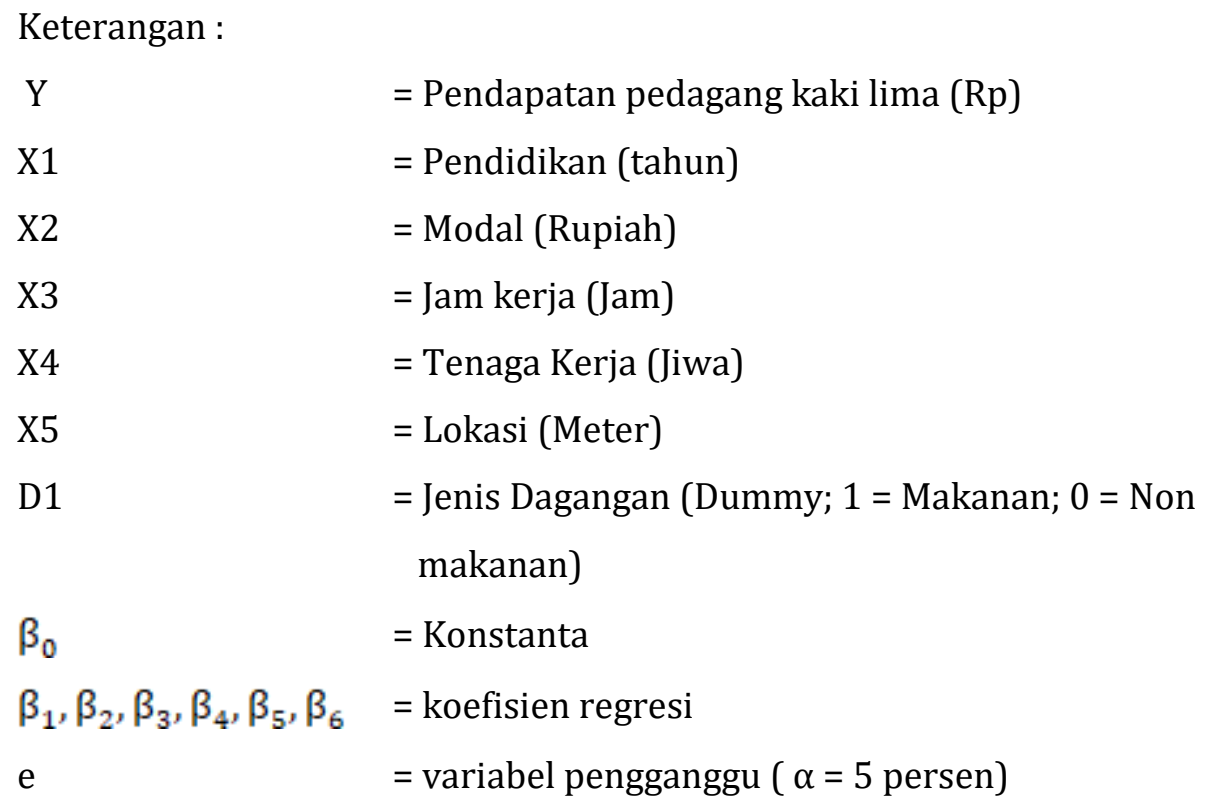

Untuk menguji ketepatan alat analisis dilakukan melalui uji asumsi klasik yang terdiri dari uji normalitas, uji multikolinearitas dan uji heteroskedastisitas (Ghozali, 2011: 103 -134). Pengujian hipotesis dilakukan melalui uji F dan uji t dengan Level of significance $(\alpha)$ sebesar 0,05 atau tingkat keyakinan 95\% dan derajat kebebasan adalah (k);(n-k-1), (Sugiyono, Metode Penelitian Bisnis, 2012). Hipotesis diterima jika $F_{\text {hitung }}$ lebih besar dari $F_{\text {tabel }}$ dan $t_{\text {hitung }}$ juga lebih besar dari $t_{\text {tabel. }}$

\section{HASIL DAN ANALISIS}

\section{Karakteristik Responden}

Pedagang kaki lima sebagai sampel di pasar Sunmor Gor Satria sebanyak 90 orang, dengan usia rata-rata berusia 37,3 tahun. Tingkat pendidikan responden mulai dari sekolah dasar sampai dengan pendidikan tinggi, sebagian besar responden 35 orang (38,8 persen) berpendidikan sekolah menengah atas, 22 orang (24,4 persen) berpendidikan tinggi. Dengan demikian dilhat dari tingkat pendidikan, sebagian besar responden 63,2 persen berpendidikan menengah keatas.

Modal usaha responden rata-rata Rp2.799.889,00, modal terendah Rp30.000,00 dan tertinggi Rp20.000.000,00. sebagaian besar responden 59 orang (65,5 persen) modal usahanya berada dalam kisaran modal rata-rata. Responden yang modal usahanya diatas Rp10.000.000,00 hanya 8 responden (8,8 persen).

Jam kerja responden adalah curahan waktu yang digunakan responden untuk berdagang, rata-rata responden berdagang sehari selama 5,23 jam, sebagaian besar responden yakni 63 responden (70 persen) mengalokasikan waktunya untuk berdagang selama 4,5 - 6 jam di pasar Sunmor yang dimulai pada jam 5.30. Sumber tenaga kerja pada responden pada 
umumnya dilakukan secara mandiri, artinya responden berdagang seorang diri. Responden yang berdagang secara mandiri sebanyak 55 responden (61 persen), menggunakan tenaga kerja satu orang 32 responden (36 persen), 2 responden menggunakan menggunakan tenaga kerja 2 orang ( 2 persen) dan seorang responden (1 persen) menggunakan tenaga kerja 3 orang.

Lokasi responden dilihat dari jarak tempat berdagang responden dengan pintu masuk wilayah Gor Satria dari sisi barat, timur dari pintu masuk utama. Lokasi terdekat adalah 2 meter dari pintu masuk dan lokasi terjauh 354 meter dari pintu masuk. Distribusi lokasi berdagang sebagian besar mendekati pintu masuk, yakni sebanyak 52 responden (57 persen), sebanyak 24 responden berada pada jarak menengah, 120 - 236 meter dari pintu masuk sebanyak 24 responden ( 27 persen) dan sebanyak 14 responden (16 persen) berada pada kategori jarak yang jauh dari pintu masuk.

Barang dagangan responden dikelompokan menjadi 2, yaitu makanan seperti aneka jenis minuman, aneka jajanan anak, dan aneka jenis bubur; dan non makanan seperti aneka jenis baju, aneka mainan anak, aneka perkakas rumah tangga dan aneka jenis assesoris. jumlah responden yang berdagang makanan sebanyak 27 orang ( 30 persen) dan non makanan sebanyak 63 orang (70 persen). Dari jenis pedagang makanan, paling banyak adalah jenis makanan yang digoreng dan dari jenis non makanan paling banyak dipergadangkan adalah baju.

Distribusi pendapatan responden berkisar antara Rp10.000,00 - Rp6.175.000,00. Sebagian besar pedagang pendapatannya sekitar Rp 2.000.000,00 yakni sebanyak 87 orang (97 persen), 2 orang pedagang ( 2 persen) pendapatannya Rp4.000.000,00 an dan seorang pedagang (1 persen) pendapatannya $\mathrm{Rp} 6.175 .000,00$.

\section{Hasil Analisis}

Hasil analisis regresi sebagai berikut :

$$
\begin{aligned}
& \operatorname{Ln} \hat{Y}=\beta_{0}+\beta_{1} X_{1}+\beta_{2} X_{2}+\beta_{3} X_{3}+\beta_{4} X_{4}+\beta_{5} X_{5}+\beta_{6} D_{1}+e \\
& \operatorname{Ln} \hat{Y}=10,341+0,055 X_{1}+0,771 X_{2}+0,052 X_{3}+0,309 X_{4}+0,001 X_{5}+0,606 D_{1}
\end{aligned}
$$

Dari hasil tersebut untuk menyatakan bahwa regresi dapat digunakan untuk memprediksi dengan baik, maka lolos uji asumsi klasik, yang meliputi uji normalitas, multikolinearitas, dan uji heteroskedastisitas.

Hasil uji normalitas menggunakan uji one sample Kolmogoroc-Smirmov, menunjukan bahwa data terdistribusi secara normal, karena nilai $p$-value $=0,384$ lebih besar dari 0,05. Uji multikolinearitas menyatakan bahwa data tidak terjadi multikolinearitas, karena nilai VIF (Variance Inflation Factor) secara keseluruhan berada diatas 0,05. Uji heteroskedastisitas dengan menggunakan Uji Glejser semua variabel $p$-value diatas $\alpha=0,05$ maka dinyatakan 
tidak terjadi adanya heteroskedastisitas. Dengan demikian maka hasil regresi dapat digunakan dengan baik untuk memprediksi pengaruh variabel-variabel yang diteliti terhadap pendapatan.

Untuk mengetahui apakah hipotesis yang menyatakan bahwa tingkat pendidikan, modal, jam kerja, jumlah tenaga kerja, lokasi usaha dan jenis dagangan berpengaruh terhadap pendapatan pedagang kaki lima di pasar Sunmor Gor Satria Purwokerto, diterima atau tidak dilakukan dengan uji secara bersama (uji F) dan secara partial (uji t). Hasil uji nilai $F_{\text {hitung }}$ 4,870 lebih besar dari nilai $\mathrm{F}_{\text {tabel }}=2,210$. Hal ini berarti variabel pendidikan, modal, jam kerja, tanaga kerja, lokasi dan jenis dagangan berpengaruh secara bersama - sama berpengaruh terhadap pendapatan, sehingga hipotesis diterima.

Hasil uji secara partial dengan nilai tabel $=1,989$, nilai $t_{\text {hitung }}$ untuk varabel-variabel terlihat pada Tabel 1. Hal ini berarti bahwa secara partial variabel yang mempengaruhi pendapatan pedagang kaki lima di pasar Sunmor Gor Satria Purwokerto hanya modal, jam kerja dan jenis dagangan karena nilai $t_{\text {hitung }}$ lebih besar dari pada nilai $t_{\text {tabel }}$; variabel lainnya yaitu pendidikan, jumlah tenaga kerja dan lokasi berjualan tidak berpengaruh.

Tabel 1. Nilai Uji t Pada Variabel-variabel Penelitian

\begin{tabular}{lccl}
\hline \multicolumn{1}{c}{ Variabel } & t hitung & t tabel & \multicolumn{1}{c}{ Keterangan } \\
\hline Pendidikan (X1) & 1,599 & 1,989 & Tidak Berpengaruh \\
Modal (X2) & 2,564 & 1,989 & Berpengaruh \\
Jam Kerja (X3) & 2,033 & 1,989 & Berpengaruh \\
Tenaga Kerja (X4) & 1,689 & 1,989 & Tidak Berpengaruh \\
Lokasi (X5) & 0,889 & 1,989 & Tidak Berpengaruh \\
Jenis Dagangan (D1) & 2,249 & 1,989 & Berpengaruh \\
\hline
\end{tabular}

Sumber : Data diolah tahun 2019

\section{Pembahasan Hasil Penelitian}

Variabel modal berpengaruh positif dan signifikan terhadap pendapatan dengan nilai koefisien regresi 0,771 ; ini berarti bahwa apabila ada kenaikan modal berdagang maka akan menaikan pendapatan pedagang sebanyak 77,1 persen. Hal ini dimungkinkan karena dengan adanya modal memungkinkan bagi pedagang untuk menyediakan berbagai alternatif kebutuhan konsumen baik dari sisi kuantitas maupun kualitasnya. Dilihat dari sisi konsumen, konsumenpun akan lebih menyukai untuk membeli barang kebutuhan pada satu lokasi atau penjual yang menyediakan berbagai macam kebutuhannya secara lengkap. Hal ini dapat kita lihat pada fenomena pasar tradisional dan pasar modern atau super market. Hasil penelitian ini sejalan dengan penelitian dari Fitria (2014), Muryati (2015), Antara (2016), Firdausa (2013), Rapunzel (2017), Butarbutar (2017), Atun (2016), Indarti (2008) dan Makorere (2017) bahwa modal akan mempengaruhi pendapatan para PKL/ pengusaha. Semakin banyak modal yang digunakan maka semakin banyak pendapatan yang diperoleh. 
Variabel jam kerja berpengaruh positif dan signifikan terhadap pendapatan, dengan nilai koefisien regresi 0,052; ini berarti bahwa apabila terdapat kenaikan jam kerja maka akan dapat meningkatkan pendapat pedagang sebesar 5,20 persen. Hal ini dimugkinkan karena dengan semakin lama waktu berjualan tentu membuka peluang bagi konsumen selanjutnya untuk melihat, datang dan membeli barang dagangannya. Temuan ini sesuai dengan penelitian Muryati (2015), Hariningsih (2008), Fitria (2014) dan Adhikari (2017) yang menyatakan bahwa jam kerja berpengaruh secara signifikan terhadap pendapatan pedagang, semakin lama seseorang berdagang akan memiliki lebih banyak waktu untuk berinteraksi dengan pembeli sehingga dapat meningkatkan pendapatan.

Variabel jenis dagangan berpengaruh positif dan signifkan terhadap pendapatan, dengan nilai koefisien regresi sebesar 0,606; ini berarti bahwa terdapat kesesuaian barang dagangan dengan kebutuhan, selera konsumen dan harga maka akan menaikan pendapatan sebesar 60,60 persen pendapatan pedagang. Hal ini dimungkinan karena dengan adanya sesuai sudah barang tentu konsumen akan membeli. Variabel jenis barang dagangan menggunakan variabel Dummy yaitu angka 1 adalah jenis dagangan berjenis makanan dan angka 0 berjenis non makanan. Artinya ketika variasi dagangan berjenis makanan bertambah 1 varian dengan asumsi variabel lain konstan maka akan menambah pengahasilan pedagang, karena konsumen dapat memilih berbagai alternatif jenis makanan yang dapat dibelinya.

Variabel pendidikan, jumlah tenaga kerja dan lokasi tidak berpengaruh terhadap pendapatan karena : 1. Kegiatan berdagang secara kaki lima memang tidak diperlukan suatu pendidikan khusus yang diperlukan adalah ketekunan dan ketrampilan dalam mencari peluang usaha terutama yang menyangkut jenis barang dagangan dan modal tentunya; 2 . Dalam usaha berdagang secara kaki lima dan dengan modal yang rata-rata sedikit, jumlah tenaga kerja yang banyak memang tidak diperlukan. Oleh karena itu kebanyakan pedagang kaki lima apalagi pada pasar yang insidental menjajakan barang dagangannya secara mandiri; 3. Lokasi dagang pada pasar Sunmor Gor Satria tidak berpengaruh karena lokasi datangnya pengunjung dapat dari berbagai arah, dan ini memberikan kesempatan pada pedagang yang berlokasi di wilayah manapun seputar Gor Satria untuk dilihat, didatangi dan dibeli barang dagangannya oleh pengunjung.

\section{KESIMPULAN}

Variabel-variabel yang mempengaruhi pendapatan pedagang kaki lima di pasar Sunmor Gor Satria Purwokerto secara bersama-sama adalah pendidikan, modal, jam kerja, tenaga kerja, lokasi dan jenis dagangan. Namun demikian dari keenam variabel yang berpengaruh secara signifikan adalah modal, jam kerja dan barang dagangan. Variabel pendidikan, jumlah tenaga kerja dan lokasi berpengaruh tidak signifikan. 


\section{IMPLIKASI}

Untuk meningkatkan pendapatan pedagang kaki lima diperlukan : 1. Upaya penambahan modal misalnya melalui program kredit khusus untuk pedagang kaki lima; 2). Memberikan peluang berdagang yang lebih lama dengan tidak mengganggu kenyamanan bagi pengguna jalan raya, misalnya dengan penyediaan fasilitas tempat khusus bagi pedagang kaki lima; dan 3). Para pedagang diharapkan dapat meningkatkan ketrampilan dalam mencari peluang pasar melalui berbagai cara, misalnya melalui pengamatan pasar, dilibatkan dalam pelatihan kewirausahaan dan seminar usaha kecil yang diselenggarakan oleh berbagai lembaga.

\section{DAFTAR PUSTAKA}

Adhikari, D. 2017. Informal Street Food Trade: A Source of Income Generation in Urban Nepal. Ecomonic Journal of Development Issues, Vol. 23 \& 24, No. 1 - 2, Hal. 1 -17.

Antara, I. K., \& Aswitari, L. P. 2016. Beberapa Faktor Yang Mempengaruhi Pendapatan Pedagang Kaki Lima di Kecamatan Denpasar Barat. Jurnal Ekonomi Pembangunan Universitas Udayana, Vol. 5, No. 11 hal. 1265 - 1291.

Ardiansyah. 2010. Analisis Faktor-Faktor Yang Mempengaruhi Pendapatan Usaha Sektor Informal di Kota Makassar (Kasus Pedagang Kaki Lima). Jurnal Dinamika Teknik, Vol. 4 No. 4 Hal 242-256.

Arikunto. 2010. Prosedur Penelitian. Jakarta: Rineka Cipta.

Atun, N. 2016. Pengaruh Modal, Lokasi dan Jenis Dagangan Terhadap Pendapatan Pedagang Pasar Prambanan Kabupaten Sleman. Jurnal Pendidikan dan Ekonomi, Vol. 5, No. 4, Hal. $318-325$.

BPS. 2018. Booklet Survai Angkatan Kerja Nasional. Sub Direktorat Statistik Ketenagakerjaan, Jakarta.

Badan Pusat Statistik. 2016. Jumlah penduduk berUsia 15 tahun keatas yang bekerja seminggu yang lalu menurut kelompok Usia dan jenis kelamin di Kabupaten Banyumas. Retrieved from banyumaskab.bps.go.id: https://banyumaskab.bps.go.id/statictable/2016/09/30/111/jumlah-pendudukberUsia-15-tahun-keatas-yang-bekerja-selama-seminggu-yang-lalu-menurutkelompok-Usia-dan-jenis-kelamin-di-kabupaten-banyumas-2015.html

Butarbutar, G. 2017. Analisis faktor-faktor yang mempengaruhi penirdapatan usaha industri makanan khas di Kota Tebing Tinggi.JOM Fekon, Vol. 4, No. 1, Hal. 619 - 633.

Darman. 2015. Kehidupan Sosial Pedagang Kaki Lima Di Kota Samarinda ( Studi Kasus Penjual Jagung Rebus Ditepian). ejournal Sosiologi Konsentrasi, Vol. 3, No. 1, Hal. 41-59.

Dickson, P., Solomon, G., \& Weaver, K. 2018. Entrepeneurial selection and success: does education matter? Journal of Small Business and Entreprise Development, Vol. 15, No. 2, HIm. 239 - 258.

Firdausa, R., \& Arianti, F. 2013. Pengaruh Modal Awal, Lama Usaha dan Jam Kerja Terhadap Pendapatan Pedagang Kios di Pasar Bintoro Demak. Diponegoro Journal Of Ecomomics, Vol. 2, No. 1, Hal. 1 - 6.

Fitria, N. A. 2014. Analisis Faktor-Faktor Yang Mempengaruhi Pendapatan Pedagang Tape Singkong Di Kota Probolinggo. (Studi Kasus Pedagang Tape Singkong Di Jln. Soekarno Hatta, Keluarahan Ketapang, Kecamatan Kademangan, Kota Probolinggo). JIM Feb Universitas Brawijaya, Vol. 2, No. 2, Hal. 1 - 11.

Ghozali. 2011. Aplikasi Analisis Multivariate dengan Program SPSS. Semarang: Badan Penerbit Universitas Diponegoro. 
Hariningsih, E., \& Simatupang, R. A. 2008. Faktor-Faktor Yang Mempengaruhi Kinerja Usaha Pedagang Eceran. Studi Kasus : Pedagang Kaki Lima di Kota Semarang. Jurnal Bisnis \& Manajemen, Vol. 4, No. 2. Hal. 25 - 40.

Indarti, N., \& Langenberg, M. 2008. Factors Affecting business success among SMEs Empirical evidences from Indonesia. researchgate, 1 - 14.

Irawan, \& Suparmoko. 2008. Ekonomika Pembangunan. Yogyakarta: BPFE- Yogyakarta.

Kuncoro, M. 2012. Perencanaan Daerah "Bagaimana membangun ekonomi lokal, kota dan kawasan". Jakarta: Salemba Empat.

Lipsey, R., Steiner, P., \& Puvis, D. 1990. Pengantar Mikroekonomi (Jilid 1). Jakarta: Erlangga.

Makorere, R., \& Kitilia, S. 2017. Intrinsic Socio-economic Factors Influencing Income From Petty (Empirical Evidence from a Case Study of Petty Traders in Dar es Salaam and). International Journal of Applied Business and Economic Research, Vol. 15, No. 5, Hal. 29 46.

Mohamad, N., Lim, H., Yusof, N., \& Soon, J. 2015. Estimating the effect of entrepreneur education on graduates' intention to be entrepreneurs", Education + Training. International Journal of Management Studies, Vol. 57, No.8, Hlm. 874 - 890.

Muryati, Akhmadi, Nurhayati, \& Parsiem. 2015. Analisis Faktor-Faktor Yang Mempengaruhi Pendapatan Pedagang Kaki Lima di Jalan Gajah Mada Muara Bulian Kabupaten Batang Hari. Jurnal Citra Ekonomi, Vol 1 No. 2, Hal. 1 - 8.

Rafiustani. 2016. Implikasi Teori Weber, Christaller dan Losch sebagai penentuan lokasi bank darah di Kota Makkasar. Perencanaan wilayah dan kota, Vol. 1, No. 1, Hal. 1 - 15.

Rapunzel, M., Rumate, V. A., \& Moslowan, I. 2017. Faktor-Faktor Yang Mempengaruhi Tingkat Pendapatan Pada Pemilik Warung Sembako di Kota Manado. Jurnal Berkala Ilmiah Efisiensi, Vol. 17, No. 02, Hal. 24 - 35.

Riduwan, \& Engkos, A. 2-12. Cara Menggunakan dan Memaknai Path Analysis (Analisis Jalur). Bandung: Alfabeta.

Simanjuntak, P. 2001. Pengantar Ekonomi Sumber Daya Manusia. . Jakarta: LPFEUI.

Soewartoyo. 2018. Pusat Penelitian Kependudukan. Retrieved from Lembaga Ilmu Pengetahuan Indonesia: lipi.go.id

Sugiyono. 2017. Statistika untuk Penelitian. Bandung: Alfabeta.

Sumarsono, S. 2009. Ekonomi Sumber Daya Manusia Teori dan Kebijakan Publik. Jakarta: Graha Ilmu.

Tarigan, R. 2006. Ekonomi Regional Teori dan Aplikasi. Jakarta: PT Bumi Aksara.

Tjiptono, F. 2008. Strategi Pemasaran. Yogyakarta: Andi.

Wicaksono, D. 2011. Analisis faktor-faktor Yang Mempengaruhi Pedagang Sektor Informal Penjual Bakso di Kota Semarang. Jurnal Perencanaan Wilayah Kota, Vol. 3 No. 4 Hal 119-124.

Wulan, S., \& Fransisca, S. 2013. Hubungan persepsi konsumen tentang lokasi usaha dengan keputusan pembelian pada UD Sinar Fajar Cabang Antasari di Bandar Lampung. Jurnal Manajemen dan Bisnis, Vol. 4,. No. 1,. Hal. 109 - 125. 